\title{
Hydrogeological and hydrogeochemical characteristics of a wider area of the regional well field Eastern Slavonia - Sikirevci
}

The Mining-Geology-Petroleum Engineering Bulletin UDC: $550.8: 556.3$

DOI: $10.17794 / \operatorname{rgn} .2016 .3 .4$

Original scientific paper

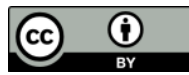

\author{
Jasna Kopić ${ }^{1}$, Jelena Loborec ${ }^{2}$, Zoran Nakić3 \\ ${ }^{1}$ Vinkovci Waterworks and Sewage Company, Dragutina Žanića-Karle 47a, Vinkovci, M.Sc. in geology \\ ${ }^{2}$ Faculty of Geotechnical Engineering, Hallerova aleja 7, Varaždin, PhD \\ ${ }^{3}$ Faculty of Mining, Geology and Petroleum Engineering, Pierottijeva 6, Zagreb, Full Professor
}

\begin{abstract}
This paper establishes hydrogeological and hydrogeochemical characteristics of a wider area of the regional well field Eastern Slavonia - Sikirevci. The research was conducted based on data gathered from the area of the Federation of Bosnia and Herzegovina and the Republic of Croatia. The aquifer Velika Kopanica is situated at the territory of the Republic of Croatia in the triangular region formed between Kopanica, Gundinci and Kruševica. The River Sava partially flows through it and the aquifer extends beneath the river to the territory of the Federation of Bosnia and Herzegovina from Donji Svilaj in the West to Domaljevac in the East where its yield is the highest. The thickness of the aquifer decreases towards the water body Odžak. It was determined that the groundwater which is extracted from wells of the wider area of the regional well field contains iron, manganese, natural ammonia and arsenic in values exceeding the maximum allowable concentration for drinking water. The increased values of these parameters are a result of mineral composition and reductive conditions in the aquifer environment. By means of a multivariate statistic cluster analysis, an overview of groups of elements is provided based on geochemical affinity and/or origin.
\end{abstract}

\section{Keywords}

Hydrogeology, hydrogeochemistry, regional well field Eastern Slavonia - Sikirevci.

\section{Introduction}

Regional hydrogeological research in the part of Eastern Slavonia along the River Sava began in the 1970s (Urumović et al., 1973), (Urumović \& Sokač (1974), (Miletić \& Urumović, 1975), (Urumović et al. (1976), (Miletić et al., 1978) with the aim of defining hydrogeological relationships in the wider study area for the purpose of solving the problem of water supply in certain communities. Based on the findings, the locations of Štitar and Županja were determined as convenient for the construction of a regional well field. Somewhat later (Miletić et al.,1978), a segmentation of the area of the Eastern Slavonia near the River Sava was proposed based on the suitability for the construction of a well field.

In the South, a gravelly aquifer is situated between the River Sava and the line Vrpolje - Cerna. Its thickness exceeds values of over $90 \mathrm{~m}$. Its lithology is mainly composed of fine to medium-sized gravel with $20 \%-50 \%$ of the weight portion of sand (Bačani, 1997). Previous hydrological research (Miletić et al., 1978) studies have shown that the most perspective area for the development of a regional well field is the area between the River Sava and the line Stari Perkovci-Velika Kopanica-Babina Greda-Štitar-Županja (see Figure 1). Groundwater in this area is recharged by inflow from the River Sava and the infiltration of precipitation (Bačani, 1997).

Based on the groundwater research (Pekaš \& Brkić, 2007) in the period from 2005 to 2008, the final location of the regional well field Eastern Slavonia was defined in the area between Gundinci and the Sava River (see Figure 1). Previous research also revealed that the aquifers in the area of Eastern Slavonia are both genetically and hydraulically linked to alluvial deposits of the River Bosnia where the regional well field Eastern Slavonia is situated (Briški et al., 
2013). The regional well field is important for its high groundwater quality. In the document called Water Management Strategy (Official Gazette 91/80) this area is marked as strategically important for the drinking water supply of the Republic of Croatia. The regional well field Eastern Slavonia with the theoretical capacity of 1000 1/s provides drinking water for about 300000 inhabitants in the area between Slavonski Brod in the West and Vinkovci, Tovarnik, Županja and Gunja in the East.

Physical, chemical and bacteriological analyses show that the groundwater at the site of the regional well field Eastern Slavonia is of high natural quality and owing to geological and hydrogeological settings, it can be well protected. However, due to agricultural production, development and urbanisation, anthropogenic pressure is rising and it can cause the deterioration of groundwater quality. Based on the measurement of radioactivity in mineral fertilizers and water at the site of the well field in Vinkovci, it was concluded that a high concentration of uranium in surface and shallow groundwater and in the water from drainage channels is caused by the use of mineral fertilizers in agriculture (Barišić et al., 1990, 1992). Physical and chemical analyses of groundwater conducted in the study area by the internal laboratories of Vinkovci Waterworks and Sewage Company, the Croatian Institute of Public Health, Ecology Service Zagreb and the Croatian Veterinary Institute Zagreb, the Veterinary Institute Vinkovci showed that the groundwater in the captured aquifer is of good quality and that the values of certain indicators, for example arsenic, manganese or iron occasionally exceed the maximum allowable concentration for drinking water.

This article presents hydrogeological characteristics of the wider area of the regional well field Eastern Slavonia Sikirevci. Based on the gathered data and analyses conducted within regular water quality monitoring activities the paper demonstrates hydrogeochemical characteristics of the groundwater from well fields Sikirevci, Bosanski Šamac and Odžak.

\section{Data and research methodology}

The study area encompasses a wider area of the regional well field Eastern Slavonia - Sikirevci (see Figure 1). This well field is situated in the area of Brod-Posavina County, east of Slavonski Brod and west of Slavonski Šamac, between the settlement Sikirevci and the Sava River. The area of Eastern Slavonia included in the study is located between Županja in the East, Strizivojna in the North and Donji Andrijevci in the West. Due to the spatial characteristics of the captured aquifer, the study area was expanded to include the area of the Federation of Bosnia and Herzegovina, to Kostrč in the East, Donji Svilaj in the West and Odžak in the South (see Figure 1).

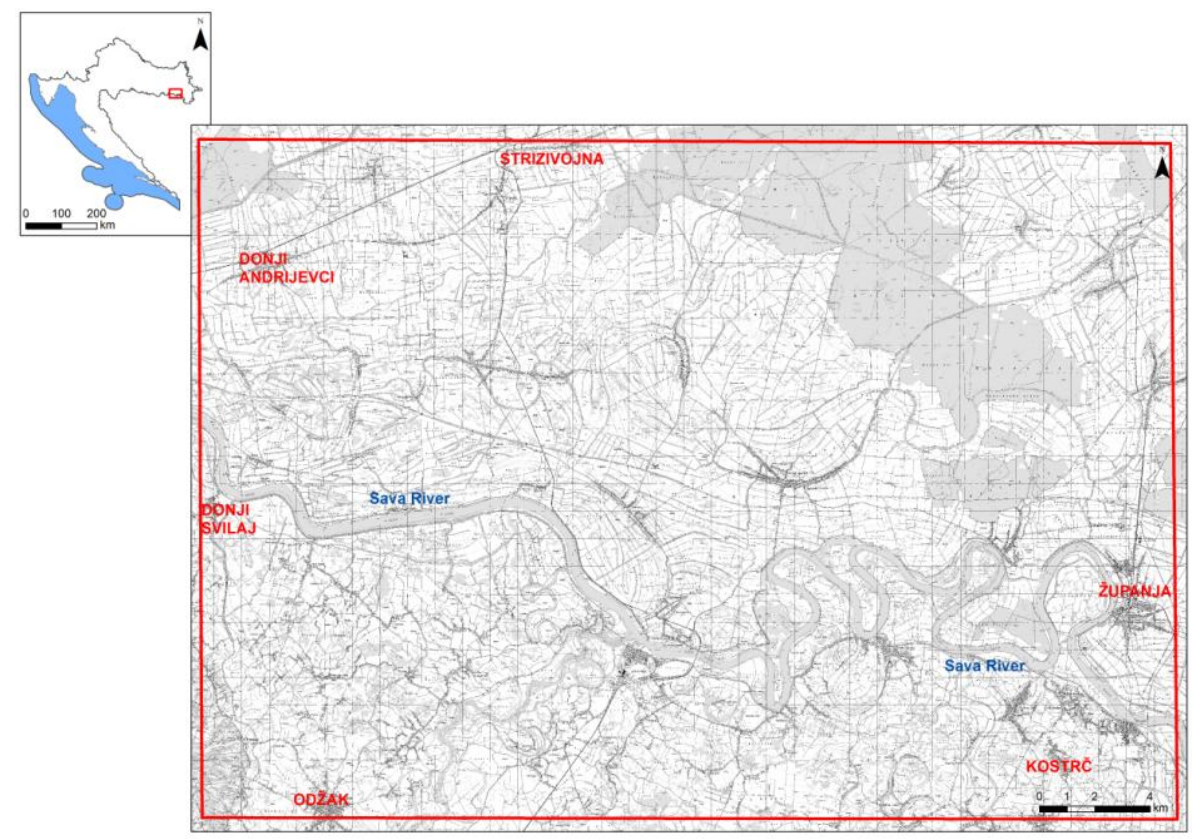

Figure 1: Location of the study area 
With the aim of defining and interpreting hydrogeological and hydrogeochemical characteristics of the study area, the following data was used in the paper:

- published and unpublished articles, technical reports and one doctoral thesis and

- results of physical, chemical and bacteriological analyses from the samples taken at the site of the regional well field

Eastern Slavonia - Sikirevci, from the well in Gundinci and the wells in Bosanski Šamac and Odžak.

The data on groundwater quality was gathered from the public water service providers Vinkovci Waterworks and Sewage Company, Croatian Geological Survey, Zagreb, Šamac Waterworks and Sewage Company and the Public Company Komunalac Ltd. Odžak as well as the Institute for Public Health of Osijek-Baranja County.

The analyses of water in the wells in Sikirevci and Gundinci were provided by the following institutions: the internal laboratory of Vinkovci Waterworks and Sewage Company, the Croatian Institute of Public Health, Ecology Service Zagreb and the Croatian Veterinary Institute Zagreb and the Veterinary Institute Vinkovci using the techniques and methods prescribed for drinking water (ASTM, 1995). The analyses cover the period from 2005 to 2014. The groundwater quality indicators for hydrogeochemical analyses from the well field in Odžak for the period from 2004 to 2010 and the well field Bosanski Šamac for the period 2005 to 2011 were also used.

By means of statistical software STATISTICA 8 (Statsoft Corp., 2006) and using R-mode cluster analysis, geochemical affinity/origin of water quality parameters were calculated. Cluster analysis is a procedure of recognizing groups or classes of similar variables, i.e. classifying a certain number of variables (quality parameters) into clusters with similar characteristics (Brown, 1998). Unlike other statistical methods, cluster analysis is frequently used in cases when statistical hypotheses to be tested have not yet been defined (Bahovec, 2011).

Cluster analysis yielded the overview of the groups of elements based on their geochemical affinity and/or origin. Hierarchical clustering resulted in a graphical model of individual clusters in the form of a hierarchical tree diagram or a dendrogram based on positive values of the correlation matrix.

The interpretation of groundwater quality was made pursuant to the Law on Water for Human Consumption ( "Zakon $o$ vodi za ljudsku potrošnju" OG 56/13; 64/15) and the Rulebook on the Parameters of Assessment and Methods of Analysis of Water for Human Consumption ("Pravilnik o parametrima sukladnosti i metodama analize vode za ljudsku potrošnju” OG 125/13; 141/13).

\section{Hydrogeological characteristics of a wider area of the regional well field Eastern Slavonia - Sikirevci}

In the wider study area, shallow unconfined and semi-confined aquifers as well as deeper subartesian unconfined and semi-confined aquifers were identified (Nakić \& Mayer, 2003). These aquifers are composed of the late Pleistocene and Quaternary deposits. The depth decreases towards the edges of the Quaternary complex and aquifers become thinner. The basic characteristics of these deposits include a significant portion of permeable layers in the total sediment thickness with a possibility of leaking between aquifers and a relatively low level of mineralisation of water (Bačani, 1997). The aquifer thickness decreases from the Sava River to the north, and the portion of small grain-size fraction increases.

Earlier research in the area of Eastern Slavonia yielded four aquifer layers - Velika Kopanica, Vinkovci, Strizivojna and Nijemci (Miletić et al., 1986). The aquifers were named after the locations where they were drilled for the first time (Capar, 1992). It is assumed that a direct lateral or vertical connection exists between the aquifers Vinkovci and Velika Kopanica, due to the variability of the basement thickness, but the significance of this contact has not been determined yet (Bačani, 1997). Due to its areal extent and hydrogeological characteristics, Velika Kopanica is the most interesting for research in the wider area of the regional well field Eastern Slavonia. Velika Kopanica is the aquifer composed of gravel and sand with a limited extent along the River Sava and has the most favourable hydrogeological characteristics in the area between Kopanica, Gundinci and Kruševica (Capar, 1992). The River Sava partially flows through the layer and the aquifer extends beneath the river to the territory of the Federation of Bosnia and Herzegovina (see Figure 2).

Overlying deposits of the aquifer at the Croatian part of the study area are composed of silty clay and sand with frequent lenses of clay and thinner layers of sand and fine gravel and its thickness depends on the location. Sometimes it reaches over 40 meters. The aquifer is composed of gravelly sand whose thickness is 30 to 40 meters. Very often it is 
discontinued by 3-7 meters thick layers of clay and silty material. The bedrock of the aquifer is composed of clay (Pekaš \& Brkić 2007).

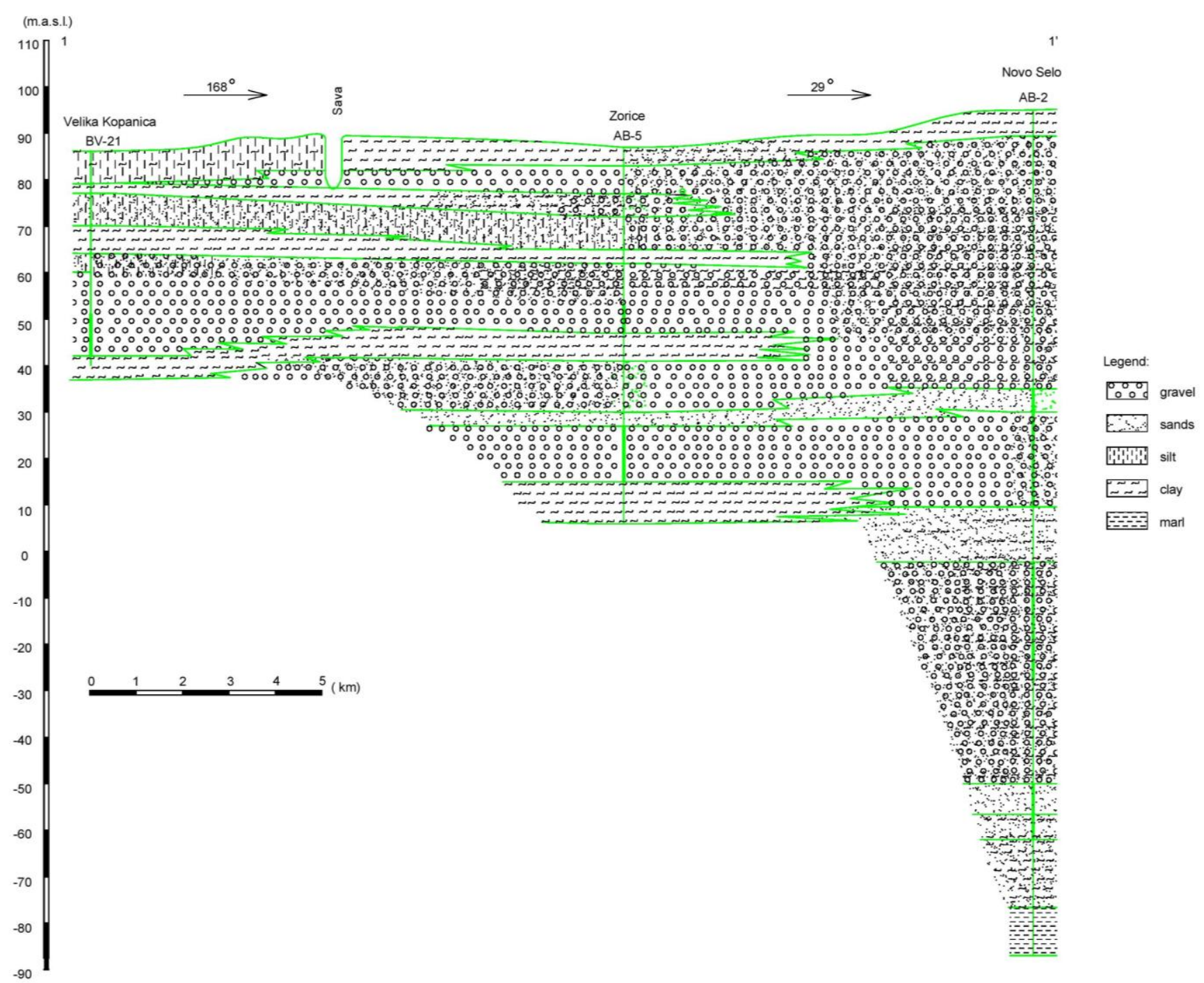

Figure 2: Lithological profile 1 - 1': Velika Kopanica - Zorice - Novo Selo

The aquifer Velika Kopanica extends beneath the Sava River to the territory of the Federation of Bosnia and Herzegovina where it is called the water body Odžak and the water body Orašje (Srkalović, 2012). The interpretation of hydrogeological relations at the territory of the Federation of Bosnia and Herzegovina was performed based on the data from the wells drilled to a depth of $200 \mathrm{~m}$ (see Figure 2).

The overlying deposits of the water body Odžak are composed of 6-14 meters of impermeable clay and silty and sandy clay (wells AB-5 and AB-2). The wells drilled in the area of the water bed Odžak descend to the groundwater much deeper since the first layer is situated at a depth of 50 to $75 \mathrm{~m}$ and the second one at a depth of $113-150 \mathrm{~m}$. The layers up to a depth of $65 \mathrm{~m}$ consist of clayey deposits, deposits of fine-sized gravel and sand which are quite clayey. The captured layers are composed of sand and medium to coarse-grained gravel. Between the gravelly layers there are 5 to 
$15 \mathrm{~m}$ thick layers of sand and clayey sand. The base is composed of clay and clayey and sandy layers. At a depth of 180 $\mathrm{m}, \mathrm{a} 15 \mathrm{~m}$ thick layer of marl was drilled at the location of Novo Selo (AB-2).

The overlying deposits of the water body Orašje is composed of clay and clayey sand the thickness of which is 5 to 10 meters (see Figure 3). The water body Orašje is composed of four gravel and sand water-bearing layers which are separated by 3 to 7 meters thick semi permeable clayey deposits. For the purpose of water supply, the wells are drilled to a depth of 70-200 meters. The first sand layer is situated at a depth of 5 to 25 meters. The second layer, composed of gravel and sand, is situated at a depth of 30 to 47 meters and the third layer at a depth of 50 to 73 meters is composed of fine to medium gravel. At the location Domaljevac, a well was drilled to a depth of $200 \mathrm{~m}$ (BD-1). By means of the core determination it was determined that the deposits at the depths of 80 to 200 meters are made of clayey gravel and sand of 80 meters thickness, with layers of clay varying from 3 to 20 meters of thickness. In addition, similar to the water body Odžak the layers of marl are drilled at a depth of 180 meters, with a total thickness of $15 \mathrm{~m}$.

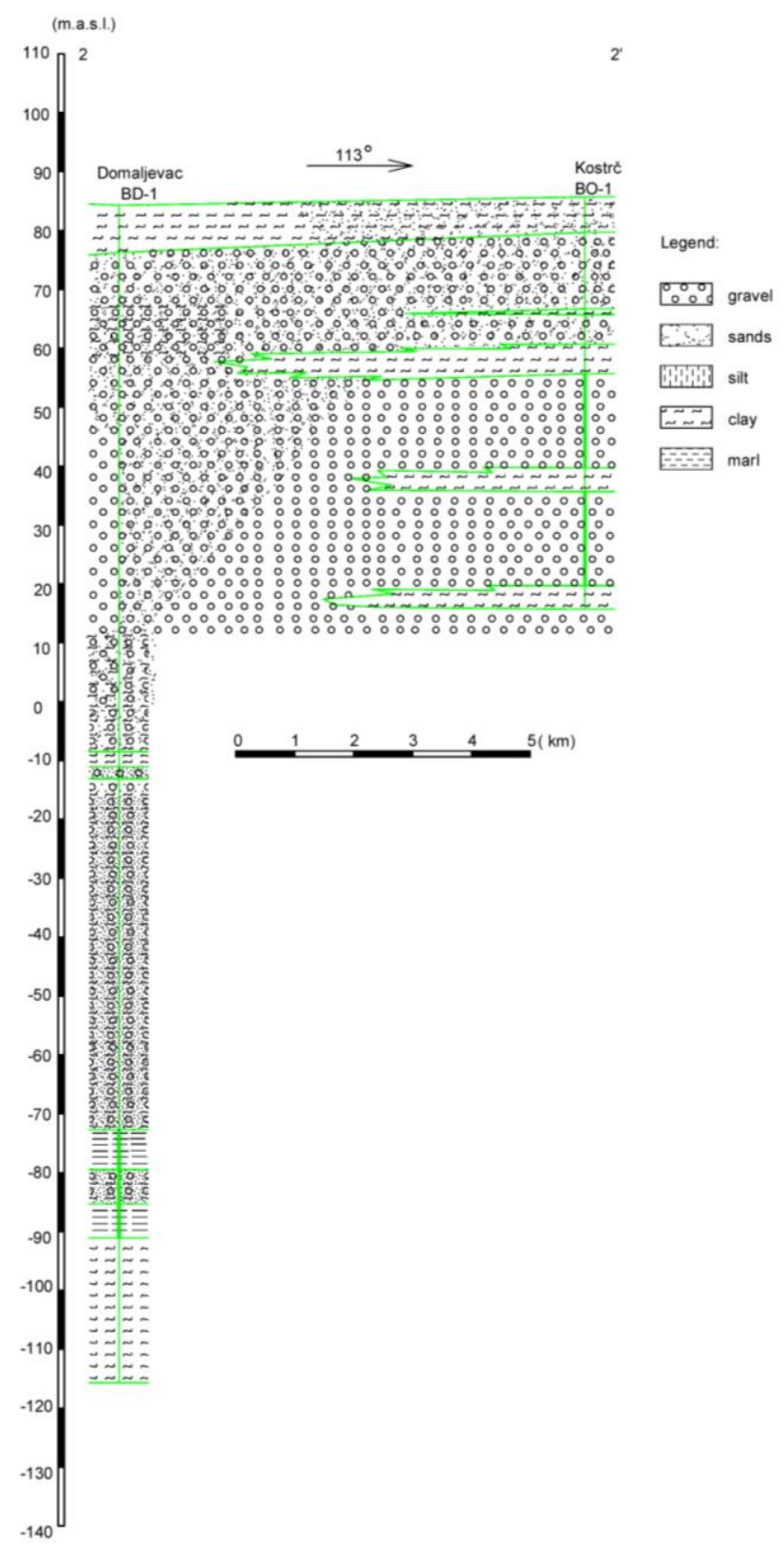

Figure 3: Lithological profile 2 - 2': Domaljevac - Kostrč 
Hydrogeological characteristics of the wider area of the regional well field Eastern Slavonia are shown on the hydrogeological map (see Figure 4). The map was created based on the data provided as the result of previously conducted research, drilling and pumping tests, as shown in Table 1. The following criteria were taken into consideration: depth to groundwater, depth to the solid rock and hydraulic conductivity. The legends are drafted based on the descriptions provided in the publication Hydrogeological Maps, a Guide and a Standard Legend of the International Association of Hydrogeologists (Struckmeier \& Margat, 1995).

Table 1: Hydrogeological parameters

\begin{tabular}{|c|c|c|c|c|}
\hline \multirow[t]{2}{*}{ No } & \multirow[t]{2}{*}{ Borehole } & $\begin{array}{l}\text { Average depth to } \\
\text { groundwater } \\
\text { (aquifer) }\end{array}$ & Depth to solid rock & $\begin{array}{c}\text { Coefficient of hydraulic } \\
\text { conductivity of the } \\
\text { aquifer }\end{array}$ \\
\hline & & (m) & (m) & $(\mathrm{m} / \mathrm{s})$ \\
\hline 1 & V-47 & 16.00 & 48.00 & $2.83 \times 10^{-2}$ \\
\hline 2 & BV-42 & 42.00 & 66.00 & $9.49 \times 10^{-4}$ \\
\hline 3 & BV-4 & 67.00 & 80.60 & $1.29 \times 10^{-3}$ \\
\hline 4 & BV-21 & 22.00 & 57.00 & $2.88 \times 10^{-3}$ \\
\hline 5 & SPB-6 & 18.12 & 74.00 & $3.65 \times 10^{-5}$ \\
\hline 6 & SPB-3 (Z-2) & 13.70 & 64.70 & $4.33 \times 10^{-3}$ \\
\hline 7 & BV-16 & 23.50 & 68.00 & $7.86 \times 10^{-4}$ \\
\hline 8 & V-48/1 & 7.40 & 96.20 & $1.4 \times 10^{-4}$ \\
\hline 9 & V-37 & 13.50 & 35.70 & $1.7 \times 10^{-3}$ \\
\hline 10 & SPB-12 (ZS-8) & 10.50 & 71.70 & $2 \times 10^{-5}$ \\
\hline 11 & SPB-7 (ZS-2) & 15.60 & 69.30 & $3.24 \times 10^{-3}$ \\
\hline 12 & SPB-9 (ZS-3) & 16.90 & 75.50 & $1.31 \times 10^{-5}$ \\
\hline 13 & V-49 (SPB-13) & 8.50 & 70.80 & $5 \times 10^{-4}$ \\
\hline 14 & SPB-8 & 8.20 & 67.00 & $2.8 \times 10^{-4}$ \\
\hline 15 & SPB-21 & 2.80 & 61.50 & $2.2 \times 10^{-4}$ \\
\hline 16 & SPB-22 & 2.00 & 65.60 & $3.4 \times 10^{-3}$ \\
\hline 17 & SPB-26 & 1.50 & 67.30 & $2.1 \times 10^{-4}$ \\
\hline 18 & SPB-15 (ZS- 4 ) & 8.90 & 68.40 & $2 \times 10^{-4}$ \\
\hline 19 & SPB-24 & 12.50 & 63.40 & $3.3 \times 10^{-4}$ \\
\hline 20 & SPB-23 & 15.80 & 61.70 & $2.2 \times 10^{-4}$ \\
\hline 21 & SPB-5 & 19.90 & 56.40 & $4.23 \times 10^{-4}$ \\
\hline 22 & SPB-11 & 14.50 & 75.40 & $1 \times 10^{-5}$ \\
\hline 23 & AB-3 & 5.40 & 168.00 & $2.43 \times 10^{-4}$ \\
\hline 24 & $A B-5$ & 10.00 & 71.00 & $1.4 \times 10^{-3}$ \\
\hline 25 & B-2 & 4.50 & 72.60 & $1.16 \times 10^{-3}$ \\
\hline 26 & BD-1 & 8.00 & 194.00 & $3.9 \times 10^{-3}$ \\
\hline 27 & AB-4 & 18.00 & 138.90 & $1 \times 10^{-5}$ \\
\hline 28 & B-2a & 16.00 & 58.50 & $2.63 \times 10^{-4}$ \\
\hline 29 & $A B-1$ & 3.00 & 193.00 & $2.51 \times 10^{-5}$ \\
\hline 30 & BV-1 & 4.00 & 74.00 & $1.4 \times 10^{-3}$ \\
\hline 31 & BO-2 & 6.00 & 66.00 & $1.2 \times 10^{-3}$ \\
\hline 32 & AB-2 & 5.90 & 156.00 & $1.2 \times 10^{-3}$ \\
\hline
\end{tabular}


In the hydrogeological map, the study area is divided into Quaternary deposits with high, medium and low transmissivity. The area with high transmissivity is situated mainly by the River Sava and at the territory of the Federation of Bosnia and Herzegovina. The aquifer is confined and semi-confined, composed of gravel and sand with high transmissivity and high hydraulic conductivity.

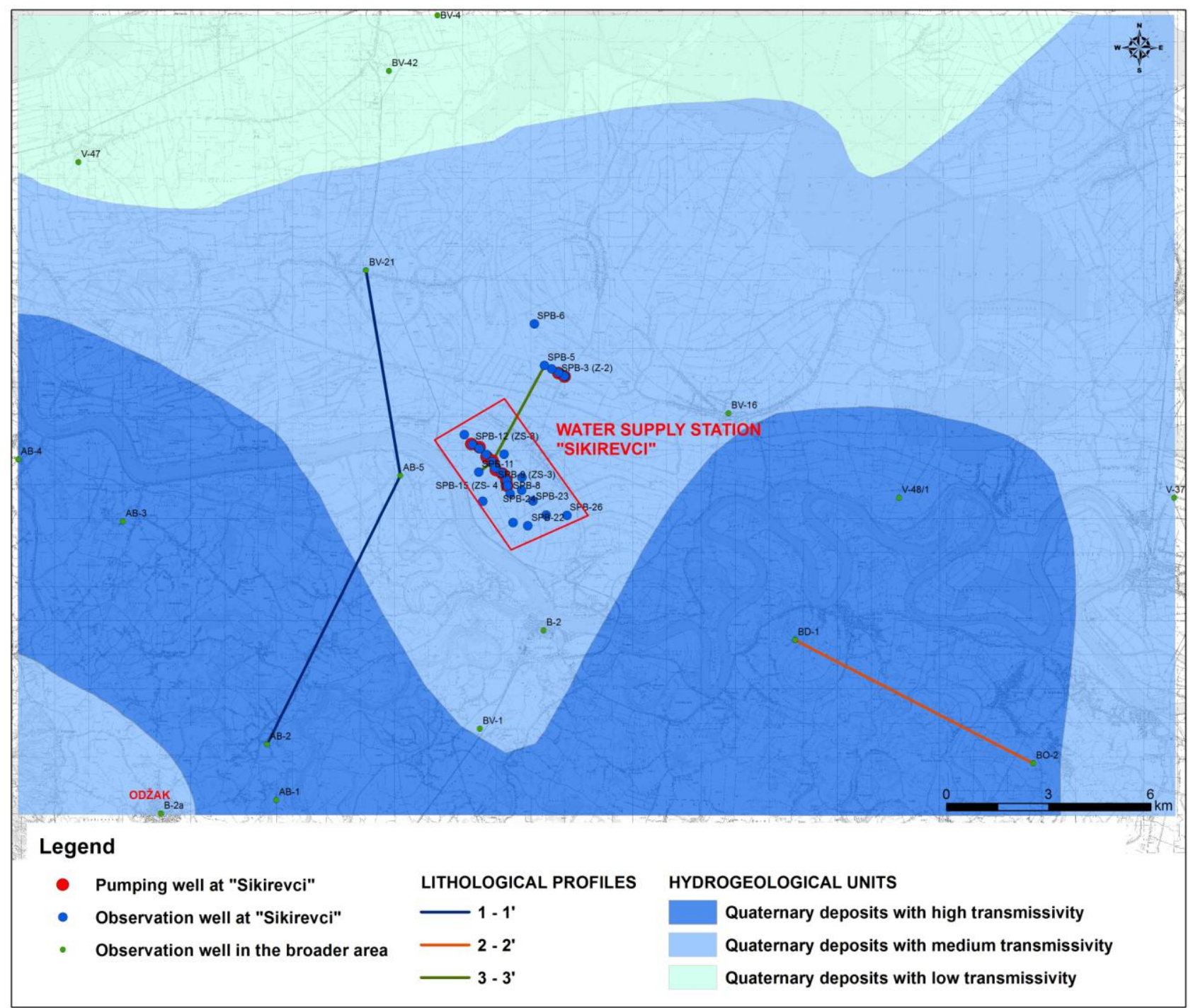

Figure 4: Hydrogeological map of the wider area of the regional well field Eastern Slavonia - Sikirevci

In the area around Odžak (see Figure 4), east and north of the deposits with high transmissivity, there are Quaternary deposits with medium transmissivity. The regional well field Eastern Slavonia - Sikirevci is situated in the area where the Quaternary deposits with medium transmissivity are captured. The aquifer is also determined as confined and semiconfined and composed of gravel and sand whose thickness attains values over 90 meters. North of the Quaternary deposits with medium transmissivity, there are deposits with transmissivity values between $1500-3000 \mathrm{~m}^{2} /$ day. The deposits are with low transmissivity and they are present within the sand aquifer whose thickness is uneven and lower in relation to the thickness of the aquifer composed of gravel and sand. 


\section{Hydrogeological and lithological characteristics at the location of the regional well field Eastern Slavonia - Sikirevci}

At the wider area of the well field "Eastern Slavonia" 26 observation wells and 9 pumping wells were put in place in the period from 2005 to 2008 (between the community of Gundinci and the River Sava) (see Figure 5).

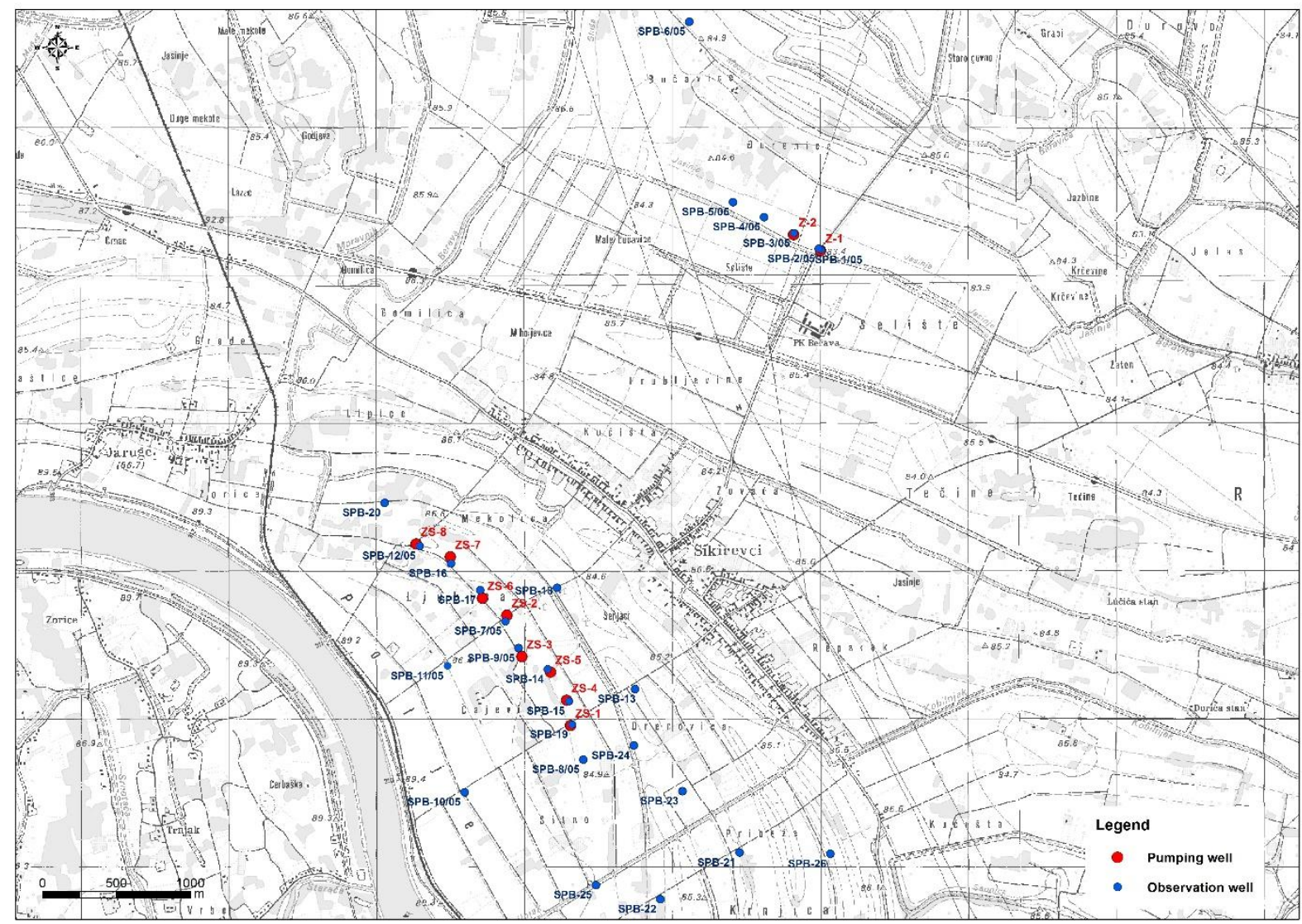

Figure 5: The position of pumping wells and monitoring wells at the location of the regional well field

Eastern Slavonia - Sikirevci

The monitoring wells were drilled to a depth from 25.7 to 96 meters and the pumping wells to a depth from 67.5 to 82 meters. Based on the data obtained during water potential study, depending on the location, three to five intervals of sand and gravel deposits were discovered.

The overlying deposits of the studied areas are mostly composed of clay 5 to 10 meters thick (see Figure 6). The clay layers alternate with the layers of clayey and sandy silt, sandy clay and clayey sand. The thickness of the covering deposits varies, depending on the location, up to a depth of 40 meters. The aquifer deposits are composed of gravelly sand and sandy gravel, which are partially clayey. These horizons are found in intervals of 29 to 36 meters, 51 to 57 meters and 69 to 75 meters. Between the first water-bearing layer, which is composed of silty and clayey gravel and the second water-bearing layer, composed of gravelly sand, there is a thin layer consisting of 3 to $4 \mathrm{~m}$ of clay (see Figure 6). Between the second and the third layer, composed of gravelly sand, there are layers of clay and silt, whose thickness is 3 to 7 meters. Within the third layer, a layer of conglomerate - cemented gravel was found with an average thickness of 10 to 29 centimetres (Pekaš \& Brkić, 2007). The base is composed of clay which was found at a depth of over 80 meters. 


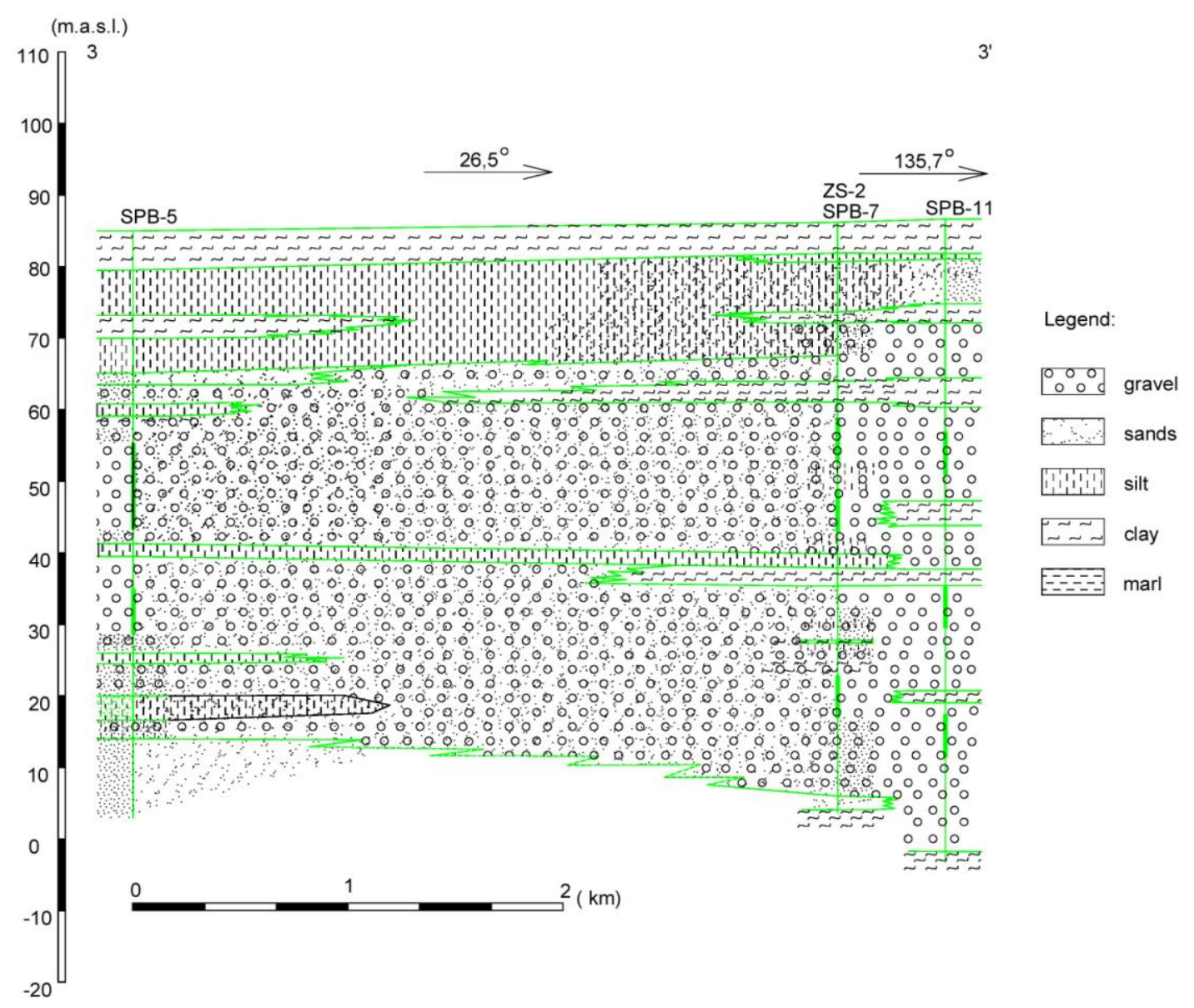

Figure 6: Lithological profile 3-3': at the location of the well field Eastern Slavonia - Sikirevci

During previous studies, it was determined that hydrogeological characteristics of the studied area are variable in the lateral and vertical profile as a result of a variable lithological structure of the studied area (Briški et al., 2013). By means of a mathematical model of the groundwater flow, it was determined that groundwater is mainly under pressure (Brkić \& Larva, 2008). The average hydraulic conductivity of the studied aquifer amounts to about $150 \mathrm{~m} / \mathrm{d}$ and the storage coefficient is $2 \times 10^{-4}$ (Briški et al., 2013).

\section{Hydrogeochemical characteristics of the groundwater of a wider area of the regional well field East Slavonia - Sikirevci}

\section{I. Hydrogeochemical characteristics of the groundwater at the site of the regional well field Eastern Slavonia - Sikirevci}

Hydrogeochemical characteristics of the groundwater at the site of the regional well field Eastern Slavonia - Sikirevci were determined based on 218 analyses of raw water from the pumping well at the well field. The water analyses concern the period from 2005 to 2014. In Table 2, basic statistical data for the parameters of the water quality at the well field are shown as well as a maximum allowable concentration, following the Rulebook on the Parameters of Assessment and Methods of Analysis of Water for Human Consumption (OG 125/13; 141/13). 
Table 2: Basic statistical parameters of raw water quality at the site Eastern Slavonia - Sikirevci

\begin{tabular}{|c|c|c|c|c|c|c|}
\hline & $\mathbf{N}$ & Mean value & Minimum & Maximum & $\begin{array}{l}\text { Standard } \\
\text { deviation }\end{array}$ & MRL \\
\hline Aluminium (mg/l) & 23 & 0.012 & $<\mathrm{DL}$ & 0.076 & 0.020 & 0.2 \\
\hline Ammonia (mg/l) & 218 & 0.055 & $<\mathrm{DL}$ & 0.580 & 0.089 & 0.5 \\
\hline Antimony $(\mu \mathrm{g} / \mathrm{l})$ & 9 & 0.022 & $<\mathrm{DL}$ & 0.200 & 0.067 & 5.0 \\
\hline Arsenic $(\mu \mathrm{g} / \mathrm{l})$ & 50 & 5.8 & $<\mathrm{DL}$ & 78.9 & 14.09 & 10 \\
\hline Copper $(\mu \mathrm{g} / \mathrm{l})$ & 18 & 0.85 & $<\mathrm{DL}$ & 4.60 & 1.48 & 2000.0 \\
\hline Barium $(\mu g / l)$ & 9 & 45.7 & 19.3 & 88.4 & 22.2 & 700 \\
\hline Colour (mg/PtCo scale) & 218 & 1.7 & $<\mathrm{DL}$ & 64.0 & 4.7 & 20 \\
\hline Zink ( $\mu g / l)$ & 18 & 16.8 & $<\mathrm{DL}$ & 106.7 & 28.3 & 3000 \\
\hline Fluoride $(\mu \mathrm{g} / \mathrm{l})$ & 13 & 75.8 & $<\mathrm{DL}$ & 148.8 & 54.4 & 1500 \\
\hline Phosphates ( $\mu \mathrm{g} / \mathrm{l})$ & 192 & 66.6 & $<\mathrm{DL}$ & 290.0 & 37.1 & 300 \\
\hline TDS dried at $105^{\circ} \mathrm{C}(\mathrm{mg} / \mathrm{l})$ & 17 & 248 & 210 & 315 & 28.6 & \\
\hline Cadmium $(\mu \mathrm{g} / \mathrm{l})$ & 13 & 0.07 & $<\mathrm{DL}$ & 0.50 & 0.14 & 5.0 \\
\hline Calcium (mg/l) & 52 & 49.2 & 37.0 & 63.2 & 4.1 & \\
\hline Potassium (mg/l) & 52 & 0.9 & 0.5 & 7.8 & 0.99 & 12 \\
\hline Chlorides (mg/l) & 178 & 4.9 & 1.2 & 23.2 & 3.2 & 250.0 \\
\hline Cobalt $(\mu \mathrm{g} / \mathrm{l})$ & 9 & 0.50 & $<\mathrm{DL}$ & 3.00 & 0.99 & \\
\hline $\mathrm{pH}$ & 174 & 7.64 & 6.98 & 8.12 & 0.24 & $6.5-9.5$ \\
\hline Chromium ( $\mu \mathrm{g} / \mathrm{l})$ & 13 & 4.2 & $<\mathrm{DL}$ & 7.3 & 2.9 & 50 \\
\hline Magnesium (mg/l) & 52 & 17.54 & 11.03 & 24.00 & 2.30 & \\
\hline Manganese $(\mu \mathrm{g} / \mathrm{l})$ & 217 & 29.76 & 0.50 & 167.3 & 24.84 & 50.0 \\
\hline Mineral oils ( $\mu \mathrm{g} / \mathrm{l})$ & 13 & 6.94 & $<\mathrm{DL}$ & 28.70 & 9.61 & \\
\hline Turbidity ( ${ }^{\circ} \mathrm{NTU}$ ) & 188 & 0.63 & $<\mathrm{DL}$ & 21.00 & 2.04 & 4 \\
\hline Sodium (mg/l) & 49 & 6.97 & 3.02 & 52.40 & 8.06 & 200.0 \\
\hline Nickel $(\mu \mathrm{g} / \mathrm{l})$ & 13 & 4.3 & $<\mathrm{DL}$ & 15.3 & 6.7 & 20 \\
\hline Nitrates (mg/l) & 218 & 2.47 & $<\mathrm{DL}$ & 8.000 & 1.13 & 50 \\
\hline Nitrites (mg/l) & 218 & 0.115 & $<\mathrm{DL}$ & 16.000 & 1.155 & 0.05 \\
\hline Lead $(\mu \mathrm{g} / \mathrm{l})$ & 17 & 0.257 & $<\mathrm{DL}$ & 1.000 & 0.337 & 10 \\
\hline Silicates (mg/l) & 14 & 9.03 & 0.60 & 24.60 & 9.07 & 50 \\
\hline Silver $(\mu \mathrm{g} / \mathrm{l})$ & 9 & 0.076 & $<\mathrm{DL}$ & 0.260 & 0.114 & 10 \\
\hline Sulphates (mg/l) & 21 & 11.9 & 3.7 & 22.7 & 4.2 & 250.0 \\
\hline Temperature $\left({ }^{\circ} \mathrm{C}\right)$ & 176 & 15.5 & 12.3 & 26.1 & 2.9 & 25 \\
\hline TOC (mg/l) & 2 & 0.28 & 0.22 & 0.34 & 0.09 & \\
\hline Total suspension $(\mathrm{mg} / \mathrm{l})$ & 12 & 71.3 & 1.8 & 255.0 & 103.6 & 10 \\
\hline $\operatorname{COD}\left(\mathrm{mgO}_{2} / \mathrm{l}\right)$ & 216 & 3.2 & $<\mathrm{DL}$ & 101.0 & 16.6 & 5.0 \\
\hline $\begin{array}{l}\text { Electrical conductivity } \\
(\mu \mathrm{S} / \mathrm{cm}) \text { at } 20^{\circ} \mathrm{C}\end{array}$ & 179 & 386.7 & 303.0 & 548.0 & 21.9 & 2500 \\
\hline Iron $(\mu \mathrm{g} / \mathrm{l})$ & 218 & 101.8 & $<\mathrm{DL}$ & 1517.5 & 242.0 & 200.0 \\
\hline Mercury ( $\mu \mathrm{g} / \mathrm{l})$ & 18 & 0.1 & $<\mathrm{DL}$ & 0.3 & 0.1 & 1.0 \\
\hline
\end{tabular}

DL- detection limit; marked in red - maximum recorded values of the parameters exceeding the MRL 
At the regional well field Eastern Slavonia - Sikirevci raw water temperature varies from 12.3 to $26.10{ }^{\circ} \mathrm{C}$, raw water $\mathrm{pH}$ is neutral to weakly alkaline, i.e. from 7.0 to 8.12 . The groundwater is mostly soft to moderately hard with values from 171 to $335 \mathrm{mg} / \mathrm{C} \mathrm{CaCO}_{3}$. The level of dissolved organic matter is occasionally higher than the maximum allowable concentration for drinking water and amounts to $101 \mathrm{mg}$, which can be concluded from the values of the chemical oxygen demand (COD) expressed in $\mathrm{mg} / \mathrm{l} \mathrm{O}_{2}$. The values of free ammonium occasionally exceed the maximum allowable concentration for drinking water. The level of nitrates and phosphates is lower than the maximum allowable concentration for drinking water. The values of arsenic in the groundwater in the area of Gundinci (Z-2, SPB-4 and SPB-6) and Sikirevci (SPB-13) exceed the maximum allowable concentration for drinking water.

Naturally increased to high concentrations of arsenic are typical for the groundwater of the Pannonian Basin which encompasses parts of Hungary, Romania, Croatia, Serbia and Slovakia (Oreščanin, 2013). The type and geochemical composition of the groundwater in this area is strictly determined by lithological, sedimentological and palaeographic factors (Rowland et al., 2011). Increased concentrations of arsenic are most likely caused by the dissolution of oxidehydroxide of iron, manganese and aluminium due to reductive conditions in the aquifer (because of a high content of organic matter and/or microbiological activity), which leads to the desorption of arsenic (Ujević et al., 2010). The gravel and sand deposits at the location of the regional well field originate from southern and south-western elevations, while in the Quaternary sediments of the Slavonia-Srijem depression minerals from metamorphic rocks of Slavonia and Bosnian serpentine zone were found. Based on the interpretation of grain size and mineralogical analyses of the samples taken from the drilling fluid, it was concluded that in the mineral composition fractions of large grains are minerals originating from source rocks of different composition and from different distribution areas, but the rocks of southern origin, i.e. Bosnian serpentine zone, were still the most predominant ones (Mutić, 1993).

The groundwater $\mathrm{pH}$ values in the aquifer at the location of the regional well field Eastern Slavonia are mostly between 7 and 8 resulting from weaker processes of silicate hydrolysis. The lower chemical consumption of oxygen is a result of a lower level of dissolved organic matter in relation to groundwater from clayey and silty deposits. Due to the alteration of alumosilicates to clay minerals, a dissolution of certain mineral components within diagenetic processes takes place in which the cations: $\mathrm{Ca}^{2+}, \mathrm{Mg}^{2+}, \mathrm{Na}^{+}, \mathrm{K}^{+}$and $\mathrm{Si}$ are partially incorporated into the structure of clay minerals and partially stay in the form of free cations in an aqueous solution. The presence of increased concentrations of iron, manganese, ammonium and arsenic in the groundwater indicates the existence of a naturally reductive environment.

Based on the data of water quality, twelve analyses of the groundwater with a total of 23 measured parameters of water quality from the well field Sikirevci were chosen. By means of statistical software STATISTICA 8 and using R-mode cluster analysis, the geochemical affinity/origin of water quality parameters was determined. The hierarchical grouping method results in a graphic representation of individual groups in the form of a hierarchic tree or dendrogram based on positive values from the correlation matrix (Brown, 1998). In order to assess the similarity of geochemical affinity, i.e. origin, between the indicators of groundwater quality, Ward's method based on the analysis of variance was used. Ward's method has a strict classification requirement based on which clusters are formed in the way that the distance between individual variables is the minimum possible distance. In assessing the similarity, only one link was used, i.e. the closest one from the correlation. Pearson $r$ distance was used in the processing of the results of water quality indicators.

By analysing the dendrogram of geochemical affinity of variables in the samples of groundwater (see Figure 7) it can be deducted that the quality parameters in the water are a consequence of the dissolution of alumosilicates, mostly clay minerals, organic matter and anthropogenic input. However, the relatively small number of available complete analyses hinders the interpretation of the dendrogram. The first group of parameters/clusters composed of aluminium, ammonium, arsenic, potassium, iron, copper, manganese and lead indicates the origin of the parameters related to the hydrolysis of silicate minerals and reductive conditions of the aquifer. The second group of parameters/clusters consists of three sub-groups or sub-clusters. The first sub-group represents complex parameter affinities of different origin which are to a lesser or greater extent related to geochemical processes including the presence of organic matter and its decomposition (barium, mercury, COD, orthophosphates and sodium) and their origin can be natural and/or anthropogenic. The second sub-group is composed of sulphates, chlorides, nitrates, nitrites, zinc, silver and calcium and their origin can mostly be related to anthropogenic input (for example mineral fertilizers, natural fertilizers, domestic wastewater and the like). The third sub-group (fluorides, silicates, magnesium) represents non-reactive geochemical indicators whose origin in the groundwater of the well field Sikirevci is most likely natural. 


\section{Dendrogram for 23 Variables \\ Ward's Method \\ 1-Pearson $r$}

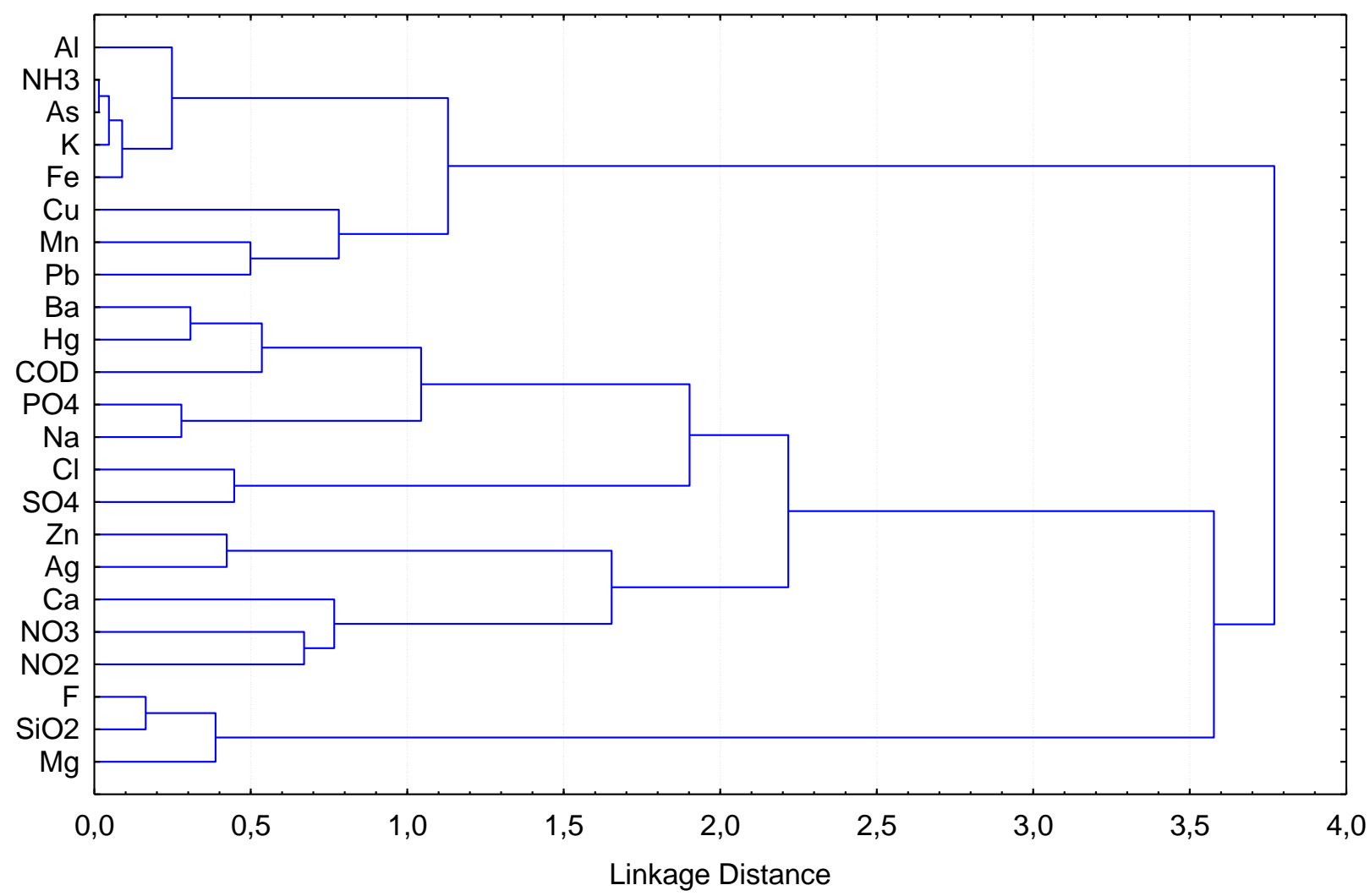

Figure 7: Dendrogram of geochemical affinity of individual variables in samples of groundwater

from the well field Eastern Slavonia-Sikirevci

\subsection{Hydrogeochemical characteristics of the groundwater at the location of the well field Bosanski Šamac}

Hydrogeochemical characteristics of the groundwater at the location of the well field Bosanski Šamac were determined based on 119 groundwater analyses. The data on the water quality were gathered from Šamac Waterworks and the Sewage Company. Table 3 shows basic statistical parameters for water quality parameters at the location and the maximum allowable concentration following the Rulebook on the Parameters of Assessment and Methods of Analysis of Water for Human Consumption (OG 125/13; 141/13). The analyses relate to the period from 2005 to 2011. 
Table 3: Basic statistical indicators of groundwater quality at the site of the pumping well of Bosanski Šamac

\begin{tabular}{|c|c|c|c|c|c|c|}
\hline & $\mathbf{N}$ & Mean value & Minimum & Maximum & $\begin{array}{l}\text { Standard } \\
\text { deviation }\end{array}$ & MRL \\
\hline Ammonia (mg/l) & 119 & 0.066 & $<\mathrm{DL}$ & 0.100 & 0.038 & 0.5 \\
\hline Copper $(\mu \mathrm{g} / \mathrm{l})$ & 5 & 1.60 & 1.00 & 2.00 & 0.55 & 2000 \\
\hline $\begin{array}{l}\text { Colour (mg/PtCo } \\
\text { scale) }\end{array}$ & 119 & 0.5 & $<\mathrm{DL}$ & 30.0 & 3.9 & 20 \\
\hline Zinc $(\mu \mathrm{g} / \mathrm{l})$ & 5 & 5.40 & 3.00 & 8.00 & 2.07 & 3000 \\
\hline $\begin{array}{l}\text { TDS dried at } 105^{\circ} \mathrm{C} \\
(\mathrm{mg} / \mathrm{l})\end{array}$ & 119 & 420.0 & 298.3 & 690.6 & 62.5 & \\
\hline Calcium (mg/l) & 14 & 131.0 & 68.9 & 208.7 & 40.7 & \\
\hline Potassium (mg/l) & 5 & 9.4 & $<\mathrm{DL}$ & 25.6 & 10.9 & 12.0 \\
\hline Chlorides (mg/l) & 119 & 51.7 & 25.2 & 68.0 & 9.4 & 250.0 \\
\hline $\mathrm{pH}$ & 119 & 7.5 & 7.2 & 8.3 & 0.2 & $6.5-9.5$ \\
\hline Chromium ( $\mu \mathrm{g} / \mathrm{l})$ & 5 & 1.4 & 1.0 & 2.0 & 0.5 & 50 \\
\hline Magnesium (mg/l) & 14 & 63.6 & 38.7 & 97.6 & 17.1 & \\
\hline Sodium (mg/l) & 5 & 9.7 & $<\mathrm{DL}$ & 25.6 & 10.78 & 200.0 \\
\hline Nitrates (mg/l) & 119 & 14.03 & $<\mathrm{DL}$ & 15.0 & 14.7 & 50 \\
\hline Nitrites (mg/l) & 117 & 0.004 & $<\mathrm{DL}$ & 0.170 & 0.022 & 0.05 \\
\hline Lead $(\mu \mathrm{g} / \mathrm{l})$ & 5 & 2.0 & 1.0 & 3.0 & 1.0 & 10 \\
\hline Selenium $(\mu \mathrm{g} / \mathrm{I})$ & 5 & 5.0 & 3.0 & 7.0 & 1.6 & 10 \\
\hline Sulphates (mg/l) & 14 & 94.8 & 65.6 & 198.4 & 34.4 & 250.0 \\
\hline Temperature $\left({ }^{\circ} \mathrm{C}\right)$ & 54 & 15.9 & 8.0 & 22.9 & 2.8 & 25 \\
\hline Total hardness (mg/l) & 14 & 24.7 & 20.1 & 34.5 & 3.96 & \\
\hline $\operatorname{COD}\left(\mathrm{mg} \mathrm{O}_{2} / \mathrm{l}\right)$ & 119 & 2.8 & 1.0 & 6.5 & 1.2 & 5.0 \\
\hline $\begin{array}{l}\text { Electrical } \\
\text { conductivity }(\mu \mathrm{S} / \mathrm{cm}) \\
\text { at } 20^{\circ} \mathrm{C}\end{array}$ & 105 & 631 & 459 & 753 & 81.5 & 2500 \\
\hline Iron $(\mu \mathrm{g} / \mathrm{l})$ & 53 & 1.9 & $<\mathrm{DL}$ & 100.0 & 13.7 & 200.0 \\
\hline Mercury $(\mu \mathrm{g} / \mathrm{l})$ & 5 & 0.3 & 0.2 & 0.4 & 0.07 & 1.0 \\
\hline
\end{tabular}

DL- detection limit; marked in red - maximum recorded values of the parameters exceeding the MRL

In the area of Bosanski Šamac, raw water temperature varies from 19.91 to $22.90{ }^{0} \mathrm{C}$, pH is weakly alkaline, i.e. from 7.2 to 8.3. The groundwater is mostly soft and the total hardness is between 20.09 and $34.53 \mathrm{mg} / \mathrm{l} \mathrm{CaCO}_{3}$. The level of dissolved organic matter occasionally exceeds the maximum allowable concentration in drinking water which can be concluded from the values of COD which ranges from 1 to $6.5 \mathrm{mg}$, calculated based on the $\mathrm{KMnO}_{4}$ consumption and 
expressed in $\mathrm{mg} \mathrm{O}_{2} / \mathrm{l}$. The values of free ammonium, nitrates and nitrites do not exceed the maximum allowable concentration for drinking water.

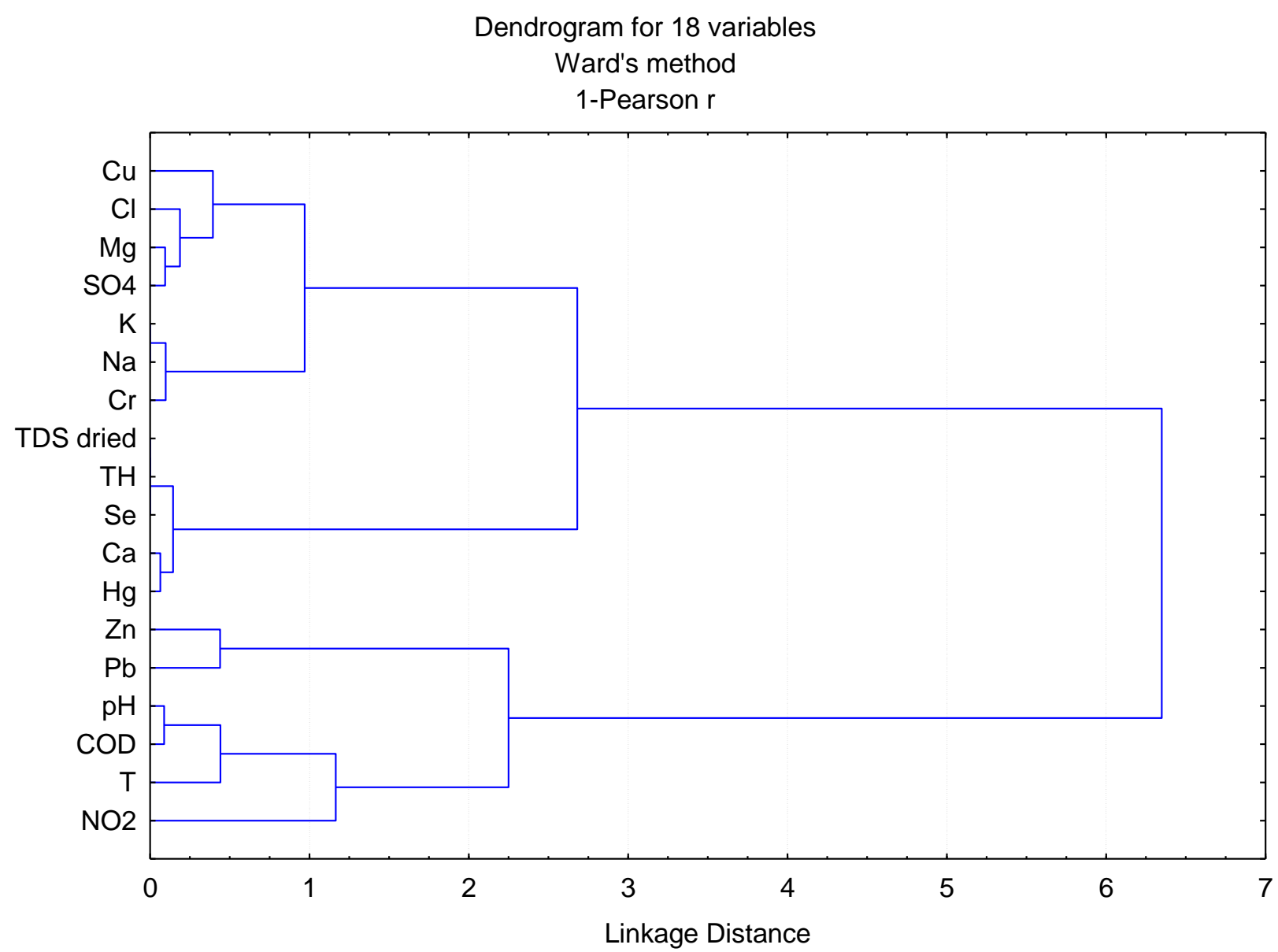

Figure 8: Dendrogram of geochemical affinity of individual parameters in samples of groundwater from the well field Bosanski Šamac

The dendrogram of the geochemical affinity/origin of water quality parameters in the samples of groundwater of the pumping well Bosanski Šamac is composed of two main groups of variables/cluster (see Figure 8). The basic origin of groundwater quality parameters/clusters of the first group of parameters indicates that the lithological profile of the aquifer includes mostly alumosilicates and partially carbonates $\left(\mathrm{Cu}, \mathrm{Cl}^{-}, \mathrm{Mg}, \mathrm{SO}_{4}{ }^{2-}, \mathrm{K}, \mathrm{Na} \mathrm{Cr}, \mathrm{Se}, \mathrm{Ca}, \mathrm{Hg}\right.$, TDS dried at $105^{\circ} \mathrm{C}$ and total hardness). The increased values of potassium and chloride ions are probably related to the use of NPK mineral fertilizers. The second group is related to the affinity and origin of the parameters associated with the present organic component in the aquifer, probably of anthropogenic origin, due to close relation with the temperature of the groundwater and the $\mathrm{pH}$ value which depends on seasonal hydrological circumstances and leaking from the terrain surface to groundwater.

\subsection{Hydrogeochemical characteristics of the groundwater at the location of the well field Odžak}

Hydrogeochemical characteristics of groundwater at the location Odžak were determined based on the data on groundwater quality from the well field Odžak. A total of 24 groundwater analyses were gathered from the Public Company Komunalac Ltd. Odžak. Table 4 shows basic statistical indicators for water quality parameters at the location 
Odžak and the maximum allowable concentration pursuant to the Rulebook on the Parameters of Assessment and Methods of Analysis of Water for Human Consumption (OG 125/13; 141/13). The analyses relate to the period from 2004 to 2010. For the pumping well in Odžak, no complete $\mathrm{C}$ analysis which would include all major cations and anions was available.

Table 4: Basic statistical indicators of groundwater quality at the site of the well field Odžak

\begin{tabular}{|c|c|c|c|c|c|c|}
\hline & $\mathbf{N}$ & Mean value & Minimum & Maximum & $\begin{array}{l}\text { Standard } \\
\text { deviation }\end{array}$ & MRL \\
\hline Ammonia (mg/l) & 24 & 0.326 & $<\mathrm{DL}$ & 0.640 & 0.227 & 0.5 \\
\hline $\begin{array}{l}\text { TDS dried } \\
\text { at } 105^{\circ} \mathrm{C}(\mathrm{mg} / \mathrm{l})\end{array}$ & 24 & 391.8 & 12.0 & 480.5 & 115.8 & \\
\hline Calcium (mg/l) & 7 & 54.2 & 44.9 & 68.1 & 9.0 & \\
\hline Chlorides (mg/l) & 24 & 15.9 & 9.1 & 29.3 & 5.0 & 250.0 \\
\hline $\mathrm{pH}$ & 24 & 7.4 & 7.0 & 7.7 & 0.2 & $6.5-9.5$ \\
\hline Magnesium (mg/l) & 8 & 39.6 & 14.9 & 101.0 & 30.6 & \\
\hline Manganese $(\mu \mathrm{g} / \mathrm{l})$ & 19 & 94.7 & 0.4 & 570.0 & 161.6 & 50.0 \\
\hline Turbidity ( $\left.{ }^{\circ} \mathrm{NTU}\right)$ & 23 & 5.6 & $<\mathrm{DL}$ & 101 & 20.8 & 4 \\
\hline Nitrates (mg/l) & 24 & 4.33 & $<\mathrm{DL}$ & 101.00 & 20.59 & 50 \\
\hline Nitrites (mg/l) & 24 & 0.004 & $<\mathrm{DL}$ & 0.048 & 0.012 & 0.05 \\
\hline Temperature $\left({ }^{\circ} \mathrm{C}\right)$ & 14 & 13.1 & 12.0 & 16.0 & 1.3 & 25 \\
\hline $\operatorname{COD}\left(\mathrm{mg} \mathrm{O}_{2} / \mathrm{l}\right)$ & 24 & 3.5 & 0.9 & 7.5 & 1.65 & 5.0 \\
\hline $\begin{array}{l}\text { Electrical } \\
\text { conductivity } \\
(\mu \mathrm{S} / \mathrm{cm}) \text { at } 20^{\circ} \mathrm{C}\end{array}$ & 19 & 584.2 & 508.0 & 621.0 & 32.0 & 2500 \\
\hline Iron $(\mu \mathrm{g} / \mathrm{l})$ & 23 & 238.3 & 20.0 & 950.0 & 272.2 & 200.0 \\
\hline
\end{tabular}

DL- detection limit ; marked in red - maximum recorded values of the parameters exceeding the MRL

At the well field Odžak, raw water temperature varies from 12 to $16^{\circ} \mathrm{C}$, raw water $\mathrm{pH}$ is neutral to weakly alkaline, i.e. from 7.0 to 7.7. The level of dissolved organic matter occasionally exceeds the maximum allowable concentration for drinking water which can be concluded from the values of oxidation potential which is $7.5 \mathrm{mg}$ and is expressed in $\mathrm{mg}$ $\mathrm{O}_{2} / 1$. The values of free ammonium, nitrates and nitrites do not exceed the minimum allowable concentration for drinking water. The dendrogram shows clearly separated variables (see Figure 9) based on their geochemical affinity and origin, i.e. two groups of parameters/clusters.

The first group of parameters/clusters includes ammonium, manganese, turbidity, nitrates and COD. This group is called the organic cluster since it groups the variables the origin of which is related to the decomposition of organic matter $\left(\mathrm{NH}_{3}, \mathrm{Mn}\right.$, turbidity, $\left.\mathrm{NO}^{3-}, \mathrm{COD}\right)$. The second group is formed by dissolved iron, calcium, magnesium, chloride ion, $\mathrm{pH}$ value, conductivity and temperature and mainly pertains to the natural geochemical environment which reflects groundwater temperature and lithological profile of the aquifer. Since no complete $\mathrm{C}$ analysis is available for groundwater at the well field Odžak, the interpretation of the dendrogram is very simplified because groundwater monitoring did not include measurements of other inorganic and organic water quality parameters. 


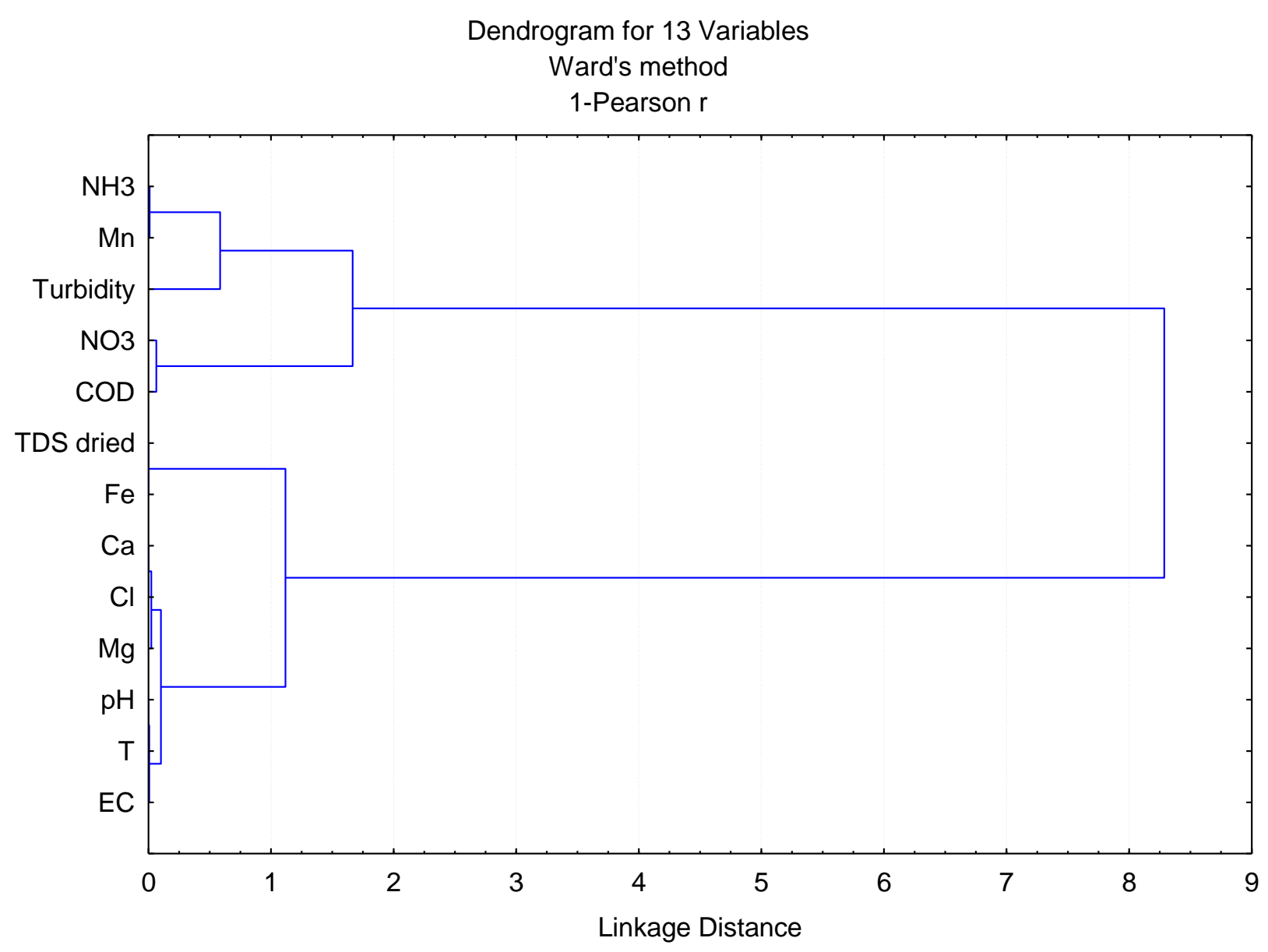

Figure 9: Dendrogram of geochemical affinity of individual variables in samples of groundwater from the well field Odžak

\subsection{Overview of geochemical characteristics of the groundwater at the wider area of the regional well field Eastern Slavonia - Sikirevci}

Based on the gathered data on the groundwater quality at the locations of Sikirevci, Bosanski Šamac and Odžak, the groundwater quality in a wider area of the regional well field Eastern Slavonia - Sikirevci was analysed. The level of iron and manganese in the groundwater in the area of Sikirevci and Odžak occasionally exceeds the maximum allowable concentration for drinking water while the values of these parameters in the groundwater in the area of Bosanski Šamac are below the maximum permissible levels (see Figure 10). In the area of Odžak, the maximum concentration of iron is $950 \mu \mathrm{g} / \mathrm{l}$ and the mean value is $238.26 \mu \mathrm{g} / \mathrm{l}$ while the maximum recorded concentration of manganese is $570 \mu \mathrm{g} / 1 \mathrm{with}$ the mean value of $94.7 \mu \mathrm{g} / \mathrm{l}$. In the area of Gundinci (Z-1, Z-2; SPB-3,4,5,) the groundwater contains increased concentrations of iron and manganese which exceed the maximum allowable concentrations for drinking water. The average concentration of iron in the groundwater in the area of the well field is $101.81 \mu \mathrm{g} / 1$ and of manganese 29.71 $\mu \mathrm{g} / \mathrm{l}$. The maximum concentration of manganese was recorded in 2004 in the well field Z-1 in Gundinci and the value was $167.30 \mu \mathrm{g} / \mathrm{l}$ while the maximum concentration of iron in Gundinci recorded in the same year amounted to 1517.5 $\mu \mathrm{g} / \mathrm{l}$ in the drilling fluid of SPB-3. 


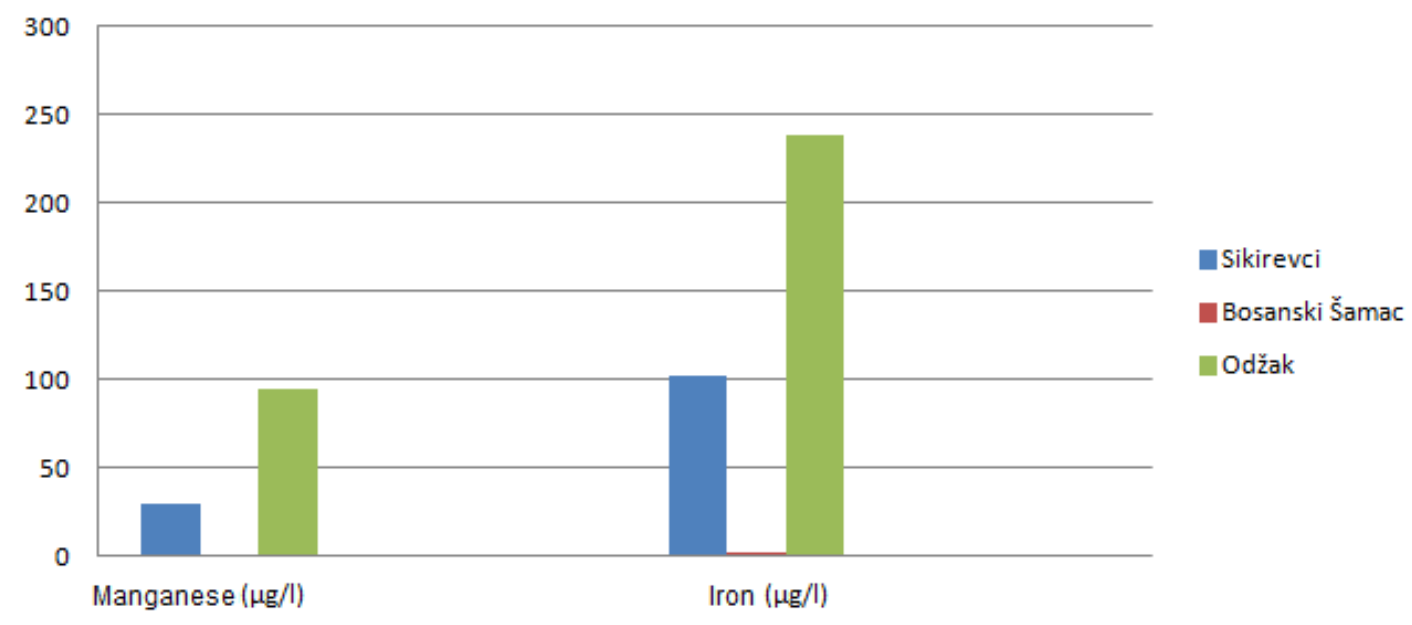

Figure 1o: A comparison of iron and manganese content in the groundwater from well fields Sikirevci, Bosanski Šamac and Odžak

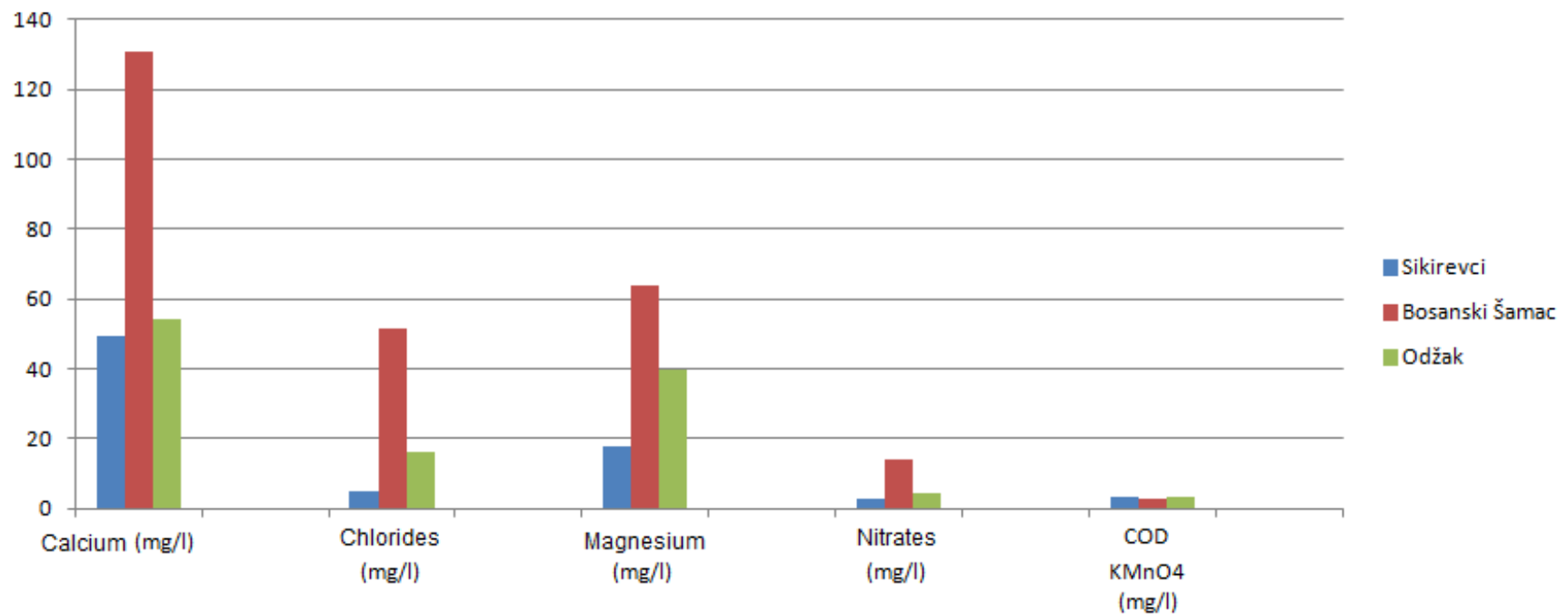

Figure 11: A comparison of potassium, chloride, magnesium and nitrate level and COD in the groundwater from well fields Sikirevci, Bosanski Šamac and Odžak

The level of calcium in all three locations is between 37.30 and $208.94 \mathrm{mg} / \mathrm{l}$, chloride between 1.20 and $68.00 \mathrm{mg} / \mathrm{l}$ and nitrates from detection limit to $14.60 \mathrm{mg} / \mathrm{l}$ (see Figure 11). COD was calculated based on the consumption of $\mathrm{KMnO}_{4}$ : in the area of Sikirevci it is mostly below the maximum allowable concentration in drinking water and ranges from 0 to $1.60 \mathrm{mg} / \mathrm{l}$, in the area of Bosanski Šamac and Odžak it occasionally exceeds the maximum allowable values of concentration. In the groundwater at the location of Bosanski Šamac, COD ranges from 1.10 to $6.50 \mathrm{mgO}_{2} / 1$ and at the location Odžak from 0.90 to $7.50 \mathrm{mgO}_{2} / \mathrm{l}$. 


\section{Conclusion}

The aquifers of a wider area of the regional well field Eastern Slavonia - Sikirevci, pertain to alluvial deposits of the River Bosnia. They are composed of gravel and sand, their areal extent is restricted to the wider area along the River Sava and the most favourable hydrogeological characteristics are found in the area between Kopanica, Gundinci and Kruševica in the Republic of Croatia. The aquifer is situated from Donji Svilac in the West to Domaljevac in the East, where its yield is the highest. The aquifer thickness decreases towards the water body Odžak. Having in mind the aforementioned, it is clear that the recharge area of the regional well field Eastern Slavonia - Sikirevci is situated at the territory of both the Republic of Croatia and the Federation of Bosnia and Herzegovina. In a wider area of the regional well field Eastern Slavonia, Quaternary deposits with high, medium and low transmissivity are found. The area with very high transmissivity is situated mainly at the territory of the Federation of Bosnia and Herzegovina where gravelly and sandy aquifers with very high transmissivity and hydraulic conductivity are found. The regional well field Eastern Slavonia - Sikirevci is situated in the area where Quaternary deposits with medium transmissivity were drilled. The water-bearing layers are gravelly and sandy, confined and semi-confined, whose thickness attains values over 90 meters. Quaternary deposits with low transmissivity are characterized by sandy layers the thickness of which is uneven and lower than the deposits with medium and high transmissivity. The deposits with low transmissivity spread in the northern part of the study area and are situated around Donji Andrijevci, Strizivojna and Vrpolje.

Available analyses of the groundwater from the pumping wells in the wider area of the regional well field indicated that the concentrations of arsenic, ammonium, manganese, iron, chemical oxygen demand and nitrates often exceed the maximum allowable concentration for drinking water. Based on the analysis of the dendrogram of geochemical indicators, the geochemical affinity in the samples of the groundwater in the area of the well field Sikirevci, it can be noted that the groundwater quality is the result of the dissolution of alumosilicates, mostly clay minerals, as well as organic matter decomposition and anthropogenic input (mainly from agriculture).

At the location of the well field Eastern Slavonia, two groups of variables/clusters were yielded. The first group (aluminium, ammonium, arsenic, potassium, iron, copper, manganese and lead) indicates the origin of parameters related to hydrolysis of silicate minerals and reductive conditions of the aquifer. The second group consists of three subgroups representing complex parameter affinities of different origin that are to a lesser or greater extent related to geochemical processes including the presence of organic matter and its decomposition (barium, mercury, COD, orthophosphates, sodium) and their origin can be natural and/or anthropogenic. The dendrogram of the geochemical affinity/origin of water quality parameters in the samples of groundwater in the area of the well field Bosanski Šamac also shows the existence of two groups of variables/clusters. The first group indicates that the lithological profile of the aquifer includes mostly alumosilicates and partially carbonates $\left(\mathrm{Cu}, \mathrm{Cl}^{-}, \mathrm{Mg}, \mathrm{SO}_{4}{ }^{2-}, \mathrm{K}, \mathrm{Na} \mathrm{Cr}, \mathrm{Se}, \mathrm{Ca}, \mathrm{Hg}\right.$, TDS dried and total hardness), related to the lithology of the wider catchment area. The second group is related to the affinity and origin of the parameters associated with the present organic component in the aquifer, probably of anthropogenic origin, due to its close relation with the temperature of the groundwater and the $\mathrm{pH}$ value which depends on seasonal hydrological circumstances. The increased values of potassium and chloride in the groundwater of the pumping well in Bosanski Šamac indicate the influence of NPK mineral fertilizers. In the area of Odžak, dendrogram variables are very clearly grouped based on their geochemical affinity. The first group of variables/clusters is called the organic cluster since it groups the variables the origin of which is related to the decomposition of organic matter. The second group is formed by dissolved iron, calcium, magnesium, chloride ion, $\mathrm{pH}$ value, conductivity and temperature and mainly pertains to the natural geochemical environment which reflects the groundwater temperature and lithological profile (mineralogical content) of the aquifer.

Based on the mean values of the compared parameters, groundwater quality is clearly higher in the area of Sikirevci than in the other studied areas (Bosanski Šamac and Odžak), probably due to pollution in the section located in the Federation of Bosnia and Herzegovina. Anthropogenic pollution is probably derived from domestic wastewater due to the inexistence of public utility infrastructures and wastewater treatment facilities, as well as the unsupervised application of agrotechnical chemicals. For the purpose of groundwater quality management in the analysed crossborder area, it is necessary to harmonize a common program of monitoring both the quantity and the quality of groundwater of all water bodies. This should be preceded by detailed hydrogeological, hydrogeochemical and hydrological research with a special emphasis on the research of hydrodynamic relations between individual water bodies. The obtained results will undoubtedly contribute to a better validation of the natural and specific vulnerability of cross-border water bodies, i.e. groundwater reserves. 


\section{References}

Bačani A (1997): Značajke hidrauličkih granica vodonosnih slojeva na vododjelnici savskog i dravskog porječja u istočnoj Slavoniji.( Features of hydraulic boundary aquifers in the watershed of the Sava and Drava River basins in eastern Slavonia.) Faculty of Mining, Geology and Petroleum, University of Zagreb, (in Croatian).

Bahovec, V. (2011): Multivarijantna analiza. (Multivariate analysis), Script Faculty of Economy, University of Zagreb (in Croatian).

Barišić, D., Lulić, S. and Miletić, P. (1990): Radionuklidi u umjetnim gnojivima i njihov utjecaj na podzemne vode. (Radionuclides in fertilizers and their effects on groundwater.) Proceedings of the Yugoslav Water Pollution Control Society "Conference Water Protection 90", 442-450, Bar. (in Croatian).

Barišić, D., Lulić, S and Miletić, P. (1992): Radium and uranium in phosphate fertilizers and their impact on the radioactivity of waters. Wat. Res., 26, 5, $607-611$.

Briški, M., Brkić, Ž. and Urumović, K. (2013): Konceptualni model vodonosnog sustava na širem području Sikirevaca. (The conceptual model of groundwater system in a wider area Sikirevci). Proceedings V. Geological Consulting in Bosnia and Herzegovina), 77-78, Pale. (in Croatian).

Brkić, Ž. and Larva, O. (2008): Uspostava motrenja razina podzemne vode na području crpilišta Regionalnog vodovoda istočne Slavonije. (Establishment of a system for monitoring the level of groundwater in the area of the well field Regional Water Supply Eastern Slavonia.) Consulting - Hydrological measurements and data processing 26.-28. Studeni 2008, Plitvička jezera, 257-268, (in Croatian).

Brown, C.E. (1998): Applied Multivariate Statistics in Geohydrology and related Sciences. Springer -Verlag.

Capar, A. (1992): Poznavanje i istraženost hidrogeologije savskog sliva istočne Slavonije. (Knowing about and exploration of hydrogeology Sava River Basin of eastern Slavonia.) Mining, geology and petroleum engineering bulletin. 4, 23-35, Zagreb. (in Croatian)

Miletić, P., Urumović, K. (1975): O geološkom okviru hidrogeoloških značajki savske doline u Hrvatskoj. (About geological framework of hydrogeological characteristics of the Sava valley in Croatia.) Zbornik radova. RGN fakultet, 101-105, Zagreb.(in Croatian)

Miletić, P., Mayer, D. and A. Capar (1978): Studija rezervi podzemnih voda istočne Slavonije, II. Faza. (The study of groundwater reserves of Eastern Slavonia, II. Phase.), Faculty of Mining, Geology and Petroleum, University of Zagreb, $72 \mathrm{p}$ (in Croatian).

Miletić, P., Mayer, D., Bačani, A. and Capar, A. (1986): Prilog poznavanju hidrogeoloških značajki prve hidrogeloške zone na području istočne Slavonije. (Contribution to the hydrogeological characteristics of the first hydrogeological zone in eastern Slavonia.) Geol. Vjesnik, 39, 137-150, Zagreb. (in Croatian)

Mutić, R. (1993): Korelacija kvartara istočne Slavonije na osnovi podataka mineraloško-petrografskih analiza (Istočna Hrvatska). Dio III: Slavonsko-srijemska potolina. (Correlation of Quaternary Eastern Slavonia on the basis of mineralogical and petrographic data analysis (Eastern Croatia). Part III: Slavonia-Srijem graben.) Acta geologica, 23/1, Croatian Academy of Sciences and Arts, 1-37, Zagreb. (in Croatian)

Nakić, Z., Mayer, D. (2003): Elaborat prve faze istraživanja s prijedlogom zaštitnih zona crpilišta Vrpolje. (Elaborate of the first phase of research with a proposal of the sanitary protection zones of the wellfield Vrpolje.) RGN fakultet Zagreb. (in Croatian)

Oreščanin, V. (2013): Arsen u vodama - porijeklo, toksični učinak i metode uklanjanja. (Arsenic in the water - the origin of the toxic effect of the removal methods.) Hrvatske vode, 21/83, 7-16, Zagreb. (in Croatian)

Pekaš, Ž. and Brkić, Ž. (2007): Crpilište Regionalnog vodovoda istočne Slavonije - rezultati tridesetogodišnjih istraživanja. (The regional well field Eastern Slavonia - the results of thirty years of research.) 4. Croatian Water Conference, 16-19. Svibnja 2007, Opatija, 779-786. (in Croatian)

Rowland, H.A.L., Omoregie, E.O., Millot, R., Jimenez, C., Mertens, J., Baciu, C., Hug, S.J. and Berg, M. (2011): Geochemistry and arsenic behaviour in groundwater resources of the Pannonian Basin (Hungary and Romania). Applied Geochemistry, 26(1), 1-17.

Srkalović, D. (2010): Ranjivost vodnih tijela podzemnih voda područja sjeveroistočne Bosne. (The vulnerability of groundwater bodies northeast Bosnia) Magistarski rad. RGNF. Univerzitet u Tuzli (in Bosnian).

Struckmeier, F.W and Margat, J. (1995): Hydrogeological maps, a guide and a standard legend, IAH, Volume 17, 177 p.

Standard Methods for the Examination of Water and Wastewater, 21th edition,(1995), American Public Health Association, American Water Works Association, Water Environment Federation.

STATISTICA 8 (2006), Statsoft Corporation, Tulsa, USA.

Ujević, M., Duić, Ž., Casiot, C., Sipos, L., Santo, V., Dadić, Ž. and Halamić, J. (2010): Occurrence and geochemistry of arsenic in the groundwater of Eastern Croatia, Applied Geochemistry, 25, 1017-1029. 
Urumović, K., Miletić, P., G. Turić, G and Blašković, V. (1973): Vodoopskrba Vinkovaca. Hidrogeološke značajke i program izrade zahvata podzemnih voda. (Vinkovci water supply. Hydrogeological features and programm for development of public water supply from groundwater.) RGN fakultet, Zagreb. 18 p. (in Croatian)

Urumović, K. and Sokač A. (1974): About Quaternary sediments Županje (Eastern Slavonia, SR Croatia). (O kvartarnim naslagama Županje (istočna Slavonija, SR Hrvatska).) Geol. Vjesnik 27, 319-330, Zagreb.(in Croatian)

Urumović, K., Hernitz, Z., Šimun, J., Tišljar, J., Sokač, A. and Velić, J. (1976): Studija određivanja zaliha podzemnih voda u istočnoj Slavoniji. (Study of determining reserves of groundwater in eastern Slavonia.) RGN fakultet. Zagreb. 118 p. (in Croatian)

*Pravilnik o parametrima sukladnosti i metodama analize vode za ljudsku potrošnju (Rulebook on the Parameters of Assessment and Methods of Analysis of Water for Human Consumption) (Official Gazette 125/13; 141/13) (in Croatian)

**Strategija upravljanja vodama (Water Management Strategy) (Official Gazette 91/2008) (in Croatian)

***Zakon o vodi za ljudsku potrošnju (Law on Water for Human Consumption) (Official Gazette 56/13; 64/15) (in Croatian)

\section{Sažetak}

\section{Hidrogeološka i hidrogeokemijska svojstva širega područja regionalnog polja Istočna Slavonija - Sikirevci}

Ovim radom utvrđena su hidrogeološka i hidrogeokemijska obilježja šireg područja regionalnog crpilišta „Istočna Slavonija“ Sikirevci. Istraživanja su provedena na temelju prikupljenih podataka sa područja Federacije Bosne i Hercegovine i Republike Hrvatske. Vodonosni horizont Velika Kopanica koji se na području Republike Hrvatske nalazi u trokutu između Kopanice, Gundinaca i Kruševice, djelomično je presječen Savom te se ispod Save proteže u Bosnu i Hercegovinu, tj. entitet Federaciju Bosne i Hercegovine, od Donjeg Svilaja na zapadu do Domaljevca na istoku gdje je njegova izdašnost najveća. Debljina vodonosnog sloja se smanjuje prema vodnom tijelu Odžak. Utvrđeno je da podzemna voda koja se crpi na zdencima šireg područja regionalnog crpilišta, sadrži željezo, mangan, prirodni amonijak i arsen u koncentracijama koje prelaze maksimalno dozvoljene koncentracije za pitku vodu. Povišene vrijednosti navedenih parametara su posljedica mineralnog sastava i reduktivnih uvjeta u vodonosnoj sredini. Multivarijatnom statističkom klaster analizom dobiven je prikaz skupina parametara kakvoće vode na temelju geokemijskog afiniteta i/ili porijekla.

\section{Ključne riječi}

hidrogeologija, hidrogeokemija, regionalno crpilište „Istočna Slavonija“ Sikirevci 